Krzysztof PARZYCH

Akademia Pomorska w Słupsku

\title{
UWARUNKOWANIA ZAGOSPODAROWANIA TURYSTYCZNEGO ŁEBY
}

\section{Wstęp}

Cechą charakterystyczną wielu miejscowości nadmorskich jest dominacja funkcji turystycznej $\mathrm{w}$ ich rozwoju społeczno-ekonomicznym (JAŻEWICZ 2011, JAŻEWICZ, RYDZ 2001, MATCZAK 2005, 2006, MATCZAK, RYDZ 2001, PARZYCH 2009, 2010, SZWICHTENBERG 1995, 2006, RYDZ 2011). Sprzyjające warunki klimatyczne występujące w strefie nadmorskiej, charakteryzujące się najwyższym w okresie lata poziomem usłonecznienia i największą na tle kraju liczbą dni pogodnych, predestynują rozwój typowej turystyki wypoczynkowej (ANDRZEJEWSKA i in. 1980). W niektórych miejscowościach nadmorskich istniejące walory turystyczne umożliwiają również rozwój innych form ruchu turystycznego: turystyki krajoznawczej, uzdrowiskowej oraz różnych form turystyki kwalifikowanej. Szczególną rolę odgrywa turystyka w rozwoju społeczno-ekonomicznym mniejszych miejscowości nadmorskich, w których często usługi związane $\mathrm{z}$ organizacją i obsługą ruchu turystycznego stanowią główne źródło dochodu mieszkańców. Jednym z tego typu ośrodków jest Łeba.

Atrakcyjność turystyczną Łeby determinują obok walorów wypoczynkowych liczne walory przyrodnicze i kulturowe znajdujące się $\mathrm{w}$ bezpośrednim i dalszym sąsiedztwie kurortu. 


\section{Cel opracowania i metoda badawcza}

W niniejszym opracowaniu dokonano analizy uwarunkowań rozwoju funkcji turystycznej Łeby ze szczególnym uwzględnieniem jej zagospodarowania turystycznego. Charakterystyki podjętego problemu badawczego dokonano w kontekście uwarunkowań przyrodniczych, historycznych oraz funkcjonalnych rozwoju turystyki. Podstawą studiów była szczegółowa inwentaryzacja terenowa wszystkich elementów infrastruktury turystycznej w miejscowości i jej najbliższym otoczeniu. Przeprowadzone badania uzupełniono kwerendą w Urzędzie Miasta Łeba mającą na celu weryfikację rezultatów badań terenowych. Wykorzystano również dostępne dane z Banku Danych Lokalnych GUS w zakresie rejestracji istniejących obiektów noclegowych. Dane ilościowe oraz dotyczące struktury rodzajowej bazy noclegowej w Łebie uzupełniono wynikami kwerendy internetowej 20 wybranych portali noclegowych ewidencjonujących obiekty noclegowe w Polsce.

Identyfikacja pojemności bazy noclegowej w Polsce oraz jej struktury rodzajowej $\mathrm{w}$ miejscowościach nadmorskich nastręcza wielu trudności. Jest to wynikiem wysokiego stopnia sezonowości ruchu turystycznego, którego efektem jest funkcjonowanie wielu obiektów noclegowych nierejestrowanych w oficjalnych statystykach GUS (SzWICHTENBERG 2006). Celowe jest więc weryfikowanie stanu bazy noclegowej w miejscowościach nadmorskich przy wykorzystaniu różnych źródeł. W niniejszej pracy dokonano analizy ilościowej i jakościowej tej bazy zestawiając ze sobą dane z pięciu różnych źródeł: szczegółowej inwentaryzacji terenowej, danych statystycznych Banku Danych Lokalnych GUS, danych Centralnego Wykazu Obiektów Hotelarskich i Urzędu Miejskiego w Łebie oraz uzyskanych w drodze kwerendy witryn internetowych 20 portali ewidencjonujących bazę noclegową. Analizy jakościowej oraz ilościowej pozostałych elementów zagospodarowania turystycznego dokonano w oparciu o badania terenowe oraz kwerendy danych UM Łeba i kwerendy witryn internetowych poświęconych Łebie.

\section{Atrakcyjność turystyczna Łeby}

Łeba jest miastem zajmującym powierzchnię $14,81 \mathrm{~km}^{2}$ położonym nad rzekami Łebą i Chełst oraz w sąsiedztwie jezior Łebsko i Sarbsko, w północno-zachodniej części województwa pomorskiego, w makroregionie Pobrzeże Koszalińskie, w mezoregionie Wybrzeże Słowińskie (rys. 1). 


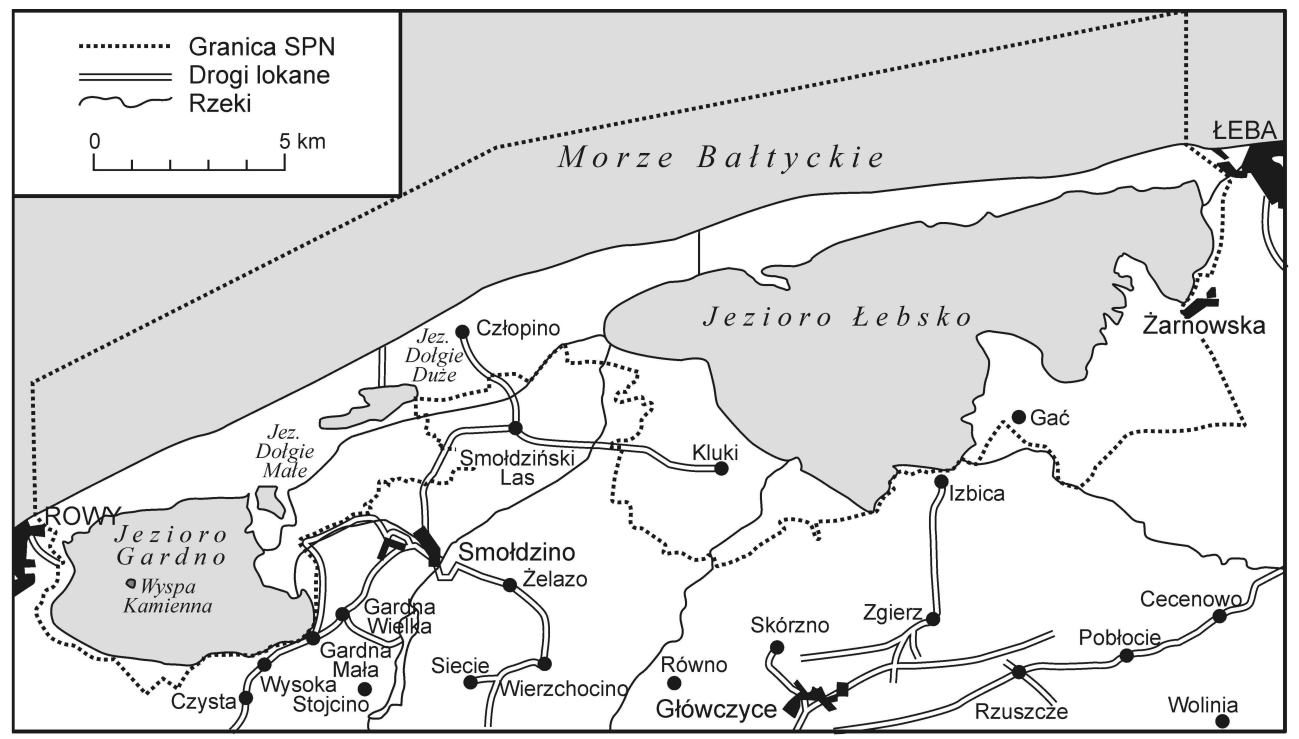

Rys. 1. Położenie geograficzne Łeby i Słowińskiego Parku Narodowego Źródło: opracowanie własne

Liczba mieszkańców miasta według stanu na 30.06.2014 r. to 3808, z tendencją malejącą w ostatnich latach. Największa liczba mieszkańców w Łebie notowana była w roku 1997 i wynosiła 4230. Od tego czasu występuje jednostajny ubytek ludności miejscowości, a gęstość zaludnienia wynosi ok. 261 osób na km².

Głównym walorem turystycznym Łeby jest jej nadmorskie położenie oraz cechy klimatu predestynujące do uprawiania typowej turystyki wypoczynkowej typu 3S. Długość sezonu kąpielowego dla Bałtyku w Łebie wynosi blisko 60 dni, natomiast dla jeziora Łebsko - 85 dni. Podstawą rozwoju turystyki jest tu strefa brzegowa. Na potrzeby turystyki i rekreacji został wyznaczony w Łebie obszar kąpieliska podzielony na trzy strefy:

1) kąpielisko centralne, przy plaży "A", obejmujące $600 \mathrm{~m}$ plaży od hotelu Neptun aż do falochronu wschodniego;

2) kąpielisko przy plaży „B”, obejmujące $200 \mathrm{~m}$ linii brzegowej - od wejścia na plażę w rejonie ulicy Turystycznej w kierunku zachodnim;

3) kąpielisko przy plaży "C", obejmujące $300 \mathrm{~m}$ linii brzegowej - od wejścia na plażę w rejonie hotelu Łeba w kierunku wschodnim.

Każda plaża w Łebie jest wyposażona w kompleks urządzeń rekreacyjnych oraz bogate zaplecze gastronomiczne i usług rozrywkowych. Wszy- 
stkie kąpieliska mają wydzielone sektory do pływania, a w obrębie każdego kąpieliska są sektory kolonijno-obozowe oraz dla grup zorganizowanych. Szerokość plaży na terenie miejscowości jest zróżnicowana i wynosi od ok. $35 \mathrm{~m}$ na plaży A - w pobliżu wejścia na plażę w rejonie ulicy Wojska Polskiego, do prawie $80 \mathrm{~m}$ w środkowej części plaży B i ok. 95-100 m na plaży C - w rejonie Białej Wydmy; w granicach Łeby znajduje się 11 wejść na plaże.

Wśród walorów krajoznawczych miejscowości godnym wymienienia jest barokowy kościół Wniebowzięcia NMP z 1683 r., który jest jedynym obiektem Łeby wpisanym do rejestru zabytków. Inne ciekawe zabytki architektury to zespół domków, zwykle z drugiej połowy XIX w. oraz z przełomu XIX i XX w. Są to w większości zabytkowe domy rybackie położone nad kanałem portowym oraz wzdłuż głównej osi układu przestrzennego miasta, jaką stanowi ulica Kościuszki. Budynki noszą liczne ślady świadczące o ich pierwotnej funkcji (okopcone fragmenty ścian po dawnych wędzarniach), stanowiąc pamiątkę historyczną pierwotnej funkcji gospodarczej Łeby.

Również interesującym zabytkiem architektury są pozostałości murów gotyckiego kościoła św. Mikołaja z XIV w. w Starej Łebie. W okolicy Łeby znajduje się również kilka atrakcyjnych obiektów dziedzictwa historyczno-kulturowego. Najatrakcyjniejszymi z punktu widzenia turystycznego są Muzeum Przyrodnicze Słowińskiego Parku Narodowego w Smołdzinie oraz Skansen Wsi Słowińskiej w Klukach. Bogactwo walorów antropogenicznych tworzą ponadto liczne zespoły sakralnej i świeckiej architektury gotyckiej Słupska i Lęborka, założenia parkowo-pałacowe, m.in. w Charbrowie, Cecenowie, Główczycach oraz inne interesujące obiekty architektoniczne.

Główną przyrodniczą atrakcją turystyczną okolic Łeby jest Słowiński Park Narodowy. Jego atrakcyjność turystyczna wiąże się z największym w Polsce kompleksem wydm nadmorskich, dużymi jeziorami przybrzeżnymi Łebsko, Gardno i Dołgie Wielkie oraz bogactwem ornitofauny'1.

Atrakcyjność Łeby podnoszą ponadto parki tematyczne: Łeba Power Park, Tarzan Park, Łeba Park - Jurajski Park Dinozaurów, Oceanarium, Sea Park w Sarbsku koło Łeby i Muzeum Motyli.

Miejscowość posiada również walory uzdrowiskowe. Chociaż Łeba nie ma statusu uzdrowiska, działalność balneologiczna była realizowana w Łebie już od 1907 r.2 Aktualnie w miejscowości funkcjonuje kilka obiektów prowadzących działalność uzdrowiskową w zakresie leczenia chorób układu

\footnotetext{
1 Słowiński Park Narodowy w roku 2005 został włączony do Listy Rezerwatów Konwencji Ramiarskiej o ochronie ekosystemów wodno-błotnych oraz ptactwa wodno-błotnego.

2. www.historialeby.pl.tl; 25.03.2015.
} 
krążenia, oddechowego oraz chorób skóry. Władze Łeby są zainteresowane rozwojem funkcji uzdrowiskowej $\mathrm{w}$ mieście i utworzeniem $\mathrm{w}$ nim uzdrowiska statutowego, czego potwierdzeniem może być fakt, że miasto od roku 2008 posiada Studium Programowo-Przestrzenne Uzdrowiska Łeba. Dokument ten stanowi koncepcję rozszerzenia funkcji turystycznej Łeby o funkcję uzdrowiskową w oparciu o istniejący potencjał walorów przyrodniczych, wyposażenie $\mathrm{w}$ infrastrukturę techniczną oraz bazę turystyczno-wypoczynkową (OŁDYKOWSKI 2008). Władze miasta od wielu lat starają się o wydłużenie sezonu turystycznego w Łebie. Jednym $z$ elementów tych działań są zabiegi o uzyskanie przez miejscowość statusu uzdrowiska. Niewątpliwie nadanie Łebie statusu prawnego uzdrowiska przyczyniłoby się do wzrostu zainteresowania miejscowością wśród turystów, także w okresie po sezonie urlopowo-wakacyjnym.

\section{Uwarunkowania historyczne rozwoju turystyki w Łebie}

Początki ruchu turystycznego w Łebie wiążą się z uruchomieniem kąpieliska miejskiego w drugiej połowie XIX w. Jego powstanie było związane z działalnością Towarzystwa Kąpielowego Badeverein, które powstało w 1862 r. ${ }^{3}$ Początkowo kąpielisko w Łebie było wykorzystywane wyłącznie przez jej mieszkańców. W drugiej połowie XIX w. dostrzeżono również walory uzdrowiskowe mikroklimatu Łeby, a pierwsza wzmianka o kąpielisku w Łebie pojawiła się w wydawanym w Niemczech „Bader Almanach” z 1898 r. W tym dokumencie zwraca się uwage na walory uzdrowiskowe kurortu wskazując na znaczenie balneologiczne Łeby przy leczeniu niedokrwistości, skrofulozy, chorób układu nerwowego, schorzeń dermatologicznych oraz układu kostnego, przede wszystkim krzywicy

Bardzo istotnym czynnikiem, który wpłynął na dalszy rozwój kąpieliska i przyczynił się do rozwoju funkcji turystycznej w ówczesnym okresie było uzyskanie przez Łebę połączenia kolejowego z sąsiednim Lęborkiem w roku 1899. Dzięki temu miejscowość stała się dostępna dla turystów zarówno z dalszych miejscowości Pomorza, jak i dla turystów z innych regionów kraju.

Nie mniej ważne dla dalszego rozwoju funkcji turystycznej miasta było powstanie w $1903 \mathrm{r}$. Towarzystwa Budownictwa Willowego w formie spółki

${ }^{3}$ www.historialeby.pl.tl; 25.03.2015.

4 „Badaer Almanach” 1898, za: www.historia leby.pl.tl; 25.03.2015. 
akcyjnej z siedzibą w Łebie. Większość członków założycieli (27 osób) wywodziła się z okolicznego ziemiaństwa. Dzielnica willowa została wytyczona w rejonie współczesnych ulic Brzozowej oraz Wojska Polskiego, Nadmorskiej i Sosnowej. Na dalszy rozwój turystyki znaczący wpływ miało otwarcie w 1907 r. domu kuracyjnego (obecnie hotel Neptun). W okresie przedwojennym Łeba spełniała istotną funkcję ośrodka wypoczynkowego oraz kolonijnego ${ }^{3}$.

Wraz z kolejnymi inwestycjami w rozbudowę infrastruktury recepcyjnej oraz technicznej ogólnej miasta wzrastała liczba odwiedzających miasto turystów. Analiza ruchu turystycznego w latach 1904-1928 wskazuje na systematyczny wzrost przyjezdnych w latach 1904-1913, kiedy liczba turystów przekroczyła 1000 osób (rys. 2).

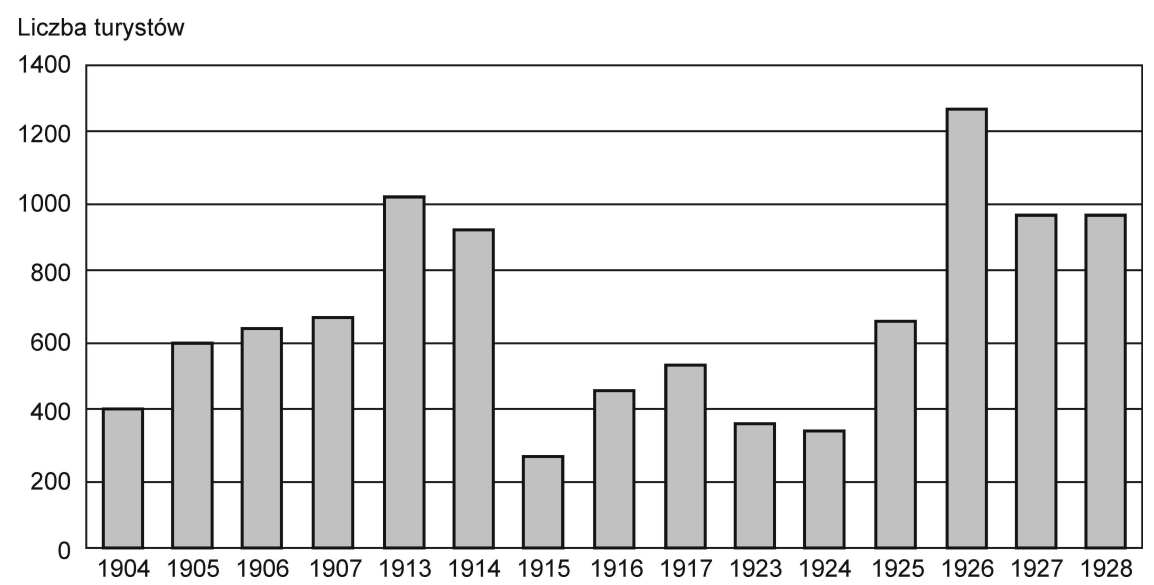

Rys. 2. Rozwój turystyki w Łebie w latach 1904-1928

Źródło: opracowanie na podstawie www.historia leby.pl.tl

W latach 1914-1918 w związku z wybuchem I wojny światowej odnotowano wyraźny spadek odwiedzających, w roku 1915 odnotowano niewiele ponad 200 turystów. Widoczny wzrost ruchu turystycznego nastąpił w latach 1924-1928 oraz kolejnych. Z czasów drugiej wojny oraz z okresu powojennego, aż do ok. 1960 r., brak jest bardziej precyzyjnych informacji dotyczących zarówno zagospodarowania noclegowego jak i ruchu turystycznego w miejscowości.

W rozwoju turystyki w Łebie w latach 1950-1990 zaznaczył się wyraźny wpływ turystyki socjalnej na funkcjonowanie i rozwój zagospodarowania 
turystycznego Łeby. Miasto stało się jednym z wiodących na polskim wybrzeżu ośrodków turystyki socjalnej organizowanej $\mathrm{w}$ ramach skierowań udzielanych z Funduszu Wczasów Pracowniczych.

Dane ilościowe nt. bazy noclegowej z 1986 r., a więc schyłku okresu z dominacją turystyki socjalnej organizowanej w przez zakłady pracy przy współudziale Funduszu Wczasów Pracowniczych, wskazują, że liczba miejsc noclegowych $\mathrm{w}$ ośrodkach zakładowych zlokalizowanych w mieście wynosiła 6106, z czego na obiekty całoroczne przypadało 1365, natomiast na miejsca sezonowe 4741. Ogółem w Łebie funkcjonowało 37 obiektów noclegowych.

Analiza pochodzenia geograficznego zakładowych ośrodków wypoczynkowych w Łebie według stanu z 1986 r. pozwala zauważyć, że większość z nich była związana z zakładami spoza obszaru obecnego województwa pomorskiego (rys. 3). Najwięcej (11) miały ich zakłady przemysłowe

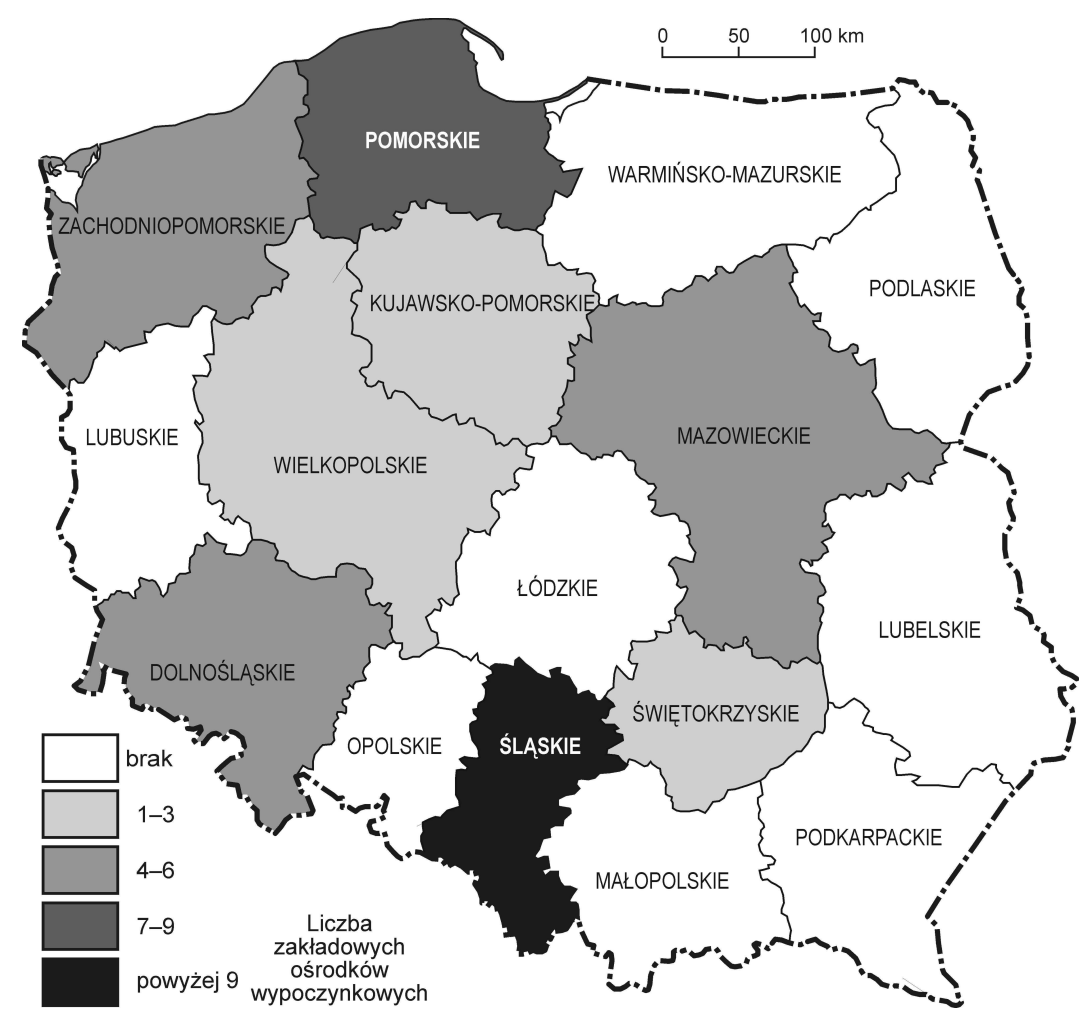

Rys. 3. Pochodzenie geograficzne zakładowych ośrodków wypoczynkowych w Łebie według stanu na rok 1986

Źródło: opracowanie własne na podstawie materiałów Urzędu Miasta w Łebie 
z województw śląskiego (najczęściej będących własnością dużych kombinatów górniczych oraz metalurgicznych dawnych województw katowickiego oraz częstochowskiego). Ponadto większą liczbę zakładowych ośrodków wczasowych $\mathrm{w}$ Łebie posiadały duże zakłady przemysłowe $\mathrm{z}$ województw pomorskiego (głównie obszar Trójmiasta), mazowieckiego (w tym przede wszystkim z Warszawy), dolnośląskiego (głównie z Wrocławia) i zachodniopomorskiego (ze Szczecina i Stargardu Szczecińskiego) (rys. 3).

Dostępne dane dotyczące zagospodarowania turystycznego Łeby z roku 1986 dotyczą informacji jedynie o zakładowych ośrodkach wypoczynkowych. Brak natomiast dokumentacji na temat obiektów indywidualnego zakwaterowania oraz innych prywatnych obiektów zakwaterowania zbiorowego z tego okresu, co nie pozwala w sposób wyczerpujący określić zasoby noclegowe kurortu w tym czasie.

\section{Struktura społeczno-ekonomiczna ludności Łeby}

Funkcjonowanie turystyki w Łebie opiera się nie tylko na bogatych walorach turystycznych, ale także na bardzo dobrze rozwiniętej infrastrukturze noclegowej oraz innych elementach szeroko rozumianej infrastruktury towarzyszącej. Jednym z istotnych mierników rozwoju funkcji turystycznej miejscowości jest, obok zagospodarowania i ruchu turystycznego, struktura społeczno-ekonomiczna jej mieszkańców, a zwłaszcza udział ludności zatrudnionej $\mathrm{w}$ zawodach związanych $\mathrm{z}$ organizacją i obsługą ruchu turystycznego w stosunku do liczby mieszkańców aktywnych zawodowo ogółem.

W społeczno-ekonomicznym rozwoju Łeby turystyka odgrywa zdecydowanie dominującą rolę. Potwierdzeniem tego są dane statystyczne dotyczące struktury rodzajowej zarejestrowanych w miejscowości podmiotów gospodarczych oraz struktury liczby osób fizycznych prowadzących działalność gospodarczą według grup sekcji PKD 2007 (rys. 4, 5).

Rysunek 4 pokazuje, że w Łebie 1110 osób fizycznych spośród prowadzących działalność gospodarczą według sekcji PKD, ponad $60 \%$ jest zatrudnionych $\mathrm{w}$ zawodach związanych bezpośrednio $\mathrm{z}$ obsługą ruchu turystycznego (sekcja I - działalność związana z zakwaterowaniem i usługami gastronomicznymi - 656 osób). Ponadto blisko 30\% osób wykonuje zawody zakwalifikowane do sekcji G i H, czyli tych, które pośrednio związane są $\mathrm{z}$ obsługą ruchu turystycznego. 


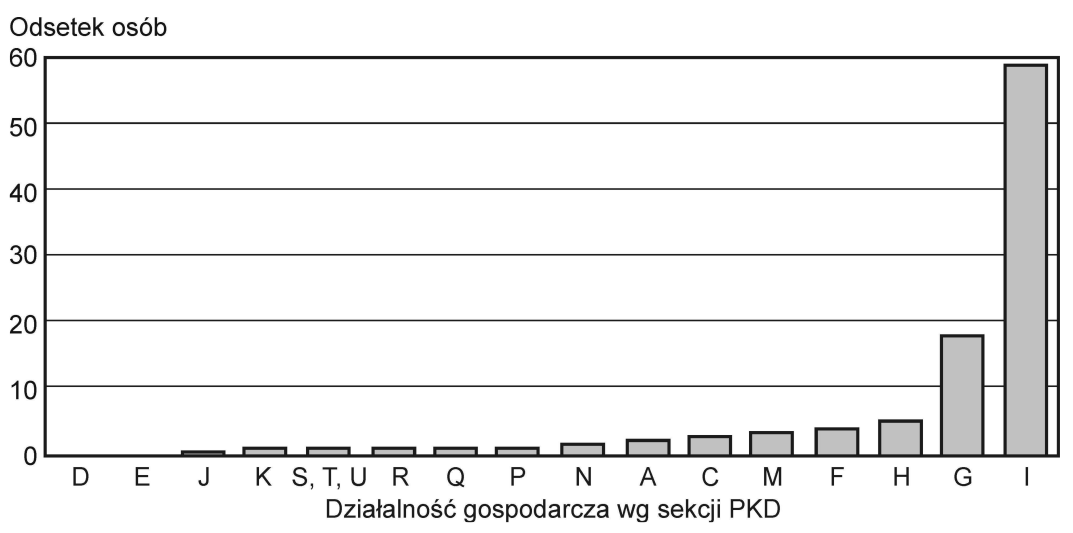

Rys. 4. Odsetek osób fizycznych prowadzących działalność gospodarczą w Łebie według sekcji PKD w 2013 r.

Źródło: opracowanie własne na podstawie Banku Danych Lokalnych GUS (www.stat.gov.com;25.03.2015)

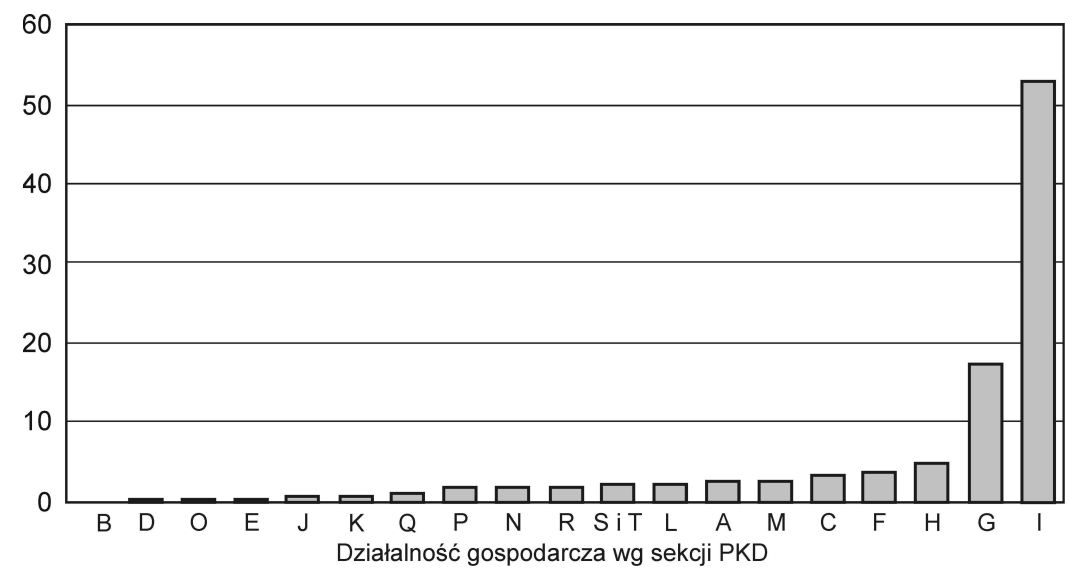

Rys. 5. Odsetek podmiotów gospodarczych prowadzących działalność gospodarczą w Łebie według sekcji PKD w 2013 r.

Źródło: opracowanie własne na podstawie Banku Danych Lokalnych GUS

Analiza liczby podmiotów gospodarczych związanych z zawodami sekcji I wynosi 714 z ogółu 1356, co stanowi 52\% wszystkich podmiotów gospodarczych zarejestrowanych w Łebie (rys. 5). Łącznie w sekcjach związanych bezpośrednio lub pośrednio z obsługą ruchu turystycznego (sekcja I, H i G) było zarejestrowanych ok. $75 \%$ podmiotów. Dane te w sposób wyraźny wskazują na dominującą rolę turystyki w rozwoju społeczno-ekonomicznym Łeby. 


\section{Analiza zagospodarowania turystycznego Łeby}

Podstawą analizy aktualnego stanu zagospodarowania Łeby - jak już wspomniano - były wyniki szczegółowych badań terenowych. Były one przeprowadzone w latach 2010-2012 w ramach ćwiczeń terenowych ze studentami III roku geografii Akademii Pomorskiej w Słupsku z zakresu zagospodarowania turystycznego gmin. Ponadto wykorzystano dane z Centralnego Wykazu Obiektów Hotelarskich, dane statystyczne GUS, dane Urzędu Miasta $\mathrm{w}$ Łebie oraz kwerendę witryn internetowych 20 wybranych portali noclegowych ewidencjonujących obiekty noclegowe $\mathrm{w}$ Polsce. $\mathrm{W}$ kwerendzie internetowej skorzystano z następujących portali: www.nocowanie.pl www. noclegi.pl, www.fajnewczasy.pl, www.turysta.pl, www.ibed.pl, www. noclegi.pl, www.eholiday.pl, www.nadmorze.pl, www.przybrzegu.pl,, www.trivago.pl, www.e-wczasy.pl,, www.noclegi-online.pl, www.meteorturystyka.pl, www.meteor.pl, www.e-nocleg.pl, www.booking.com, www. interia.pl, www.noclegiw.pl, www.szukamnoclegu.com.pl, www.inoclegi.pl.

W przypadku nadmorskich miejscowości wypoczynkowych charakteryzujących się wysokim poziomem sezonowości ruchu turystycznego wydaje się być uzasadnione wykorzystanie badań terenowych, rejestrów bazy noclegowej GUS, danych urzędów gmin i miast nadmorskich oraz kwerendy zasobów baz internetowych. Wyniki badań terenowych w połączeniu z zastosowaniem innych metod badań wtórnych stwarzają możliwość uzyskania najbardziej wiarygodnego obrazu pojemności i struktury rodzajowej bazy noclegowej nadmorskich turystycznych jednostek przestrzennych.

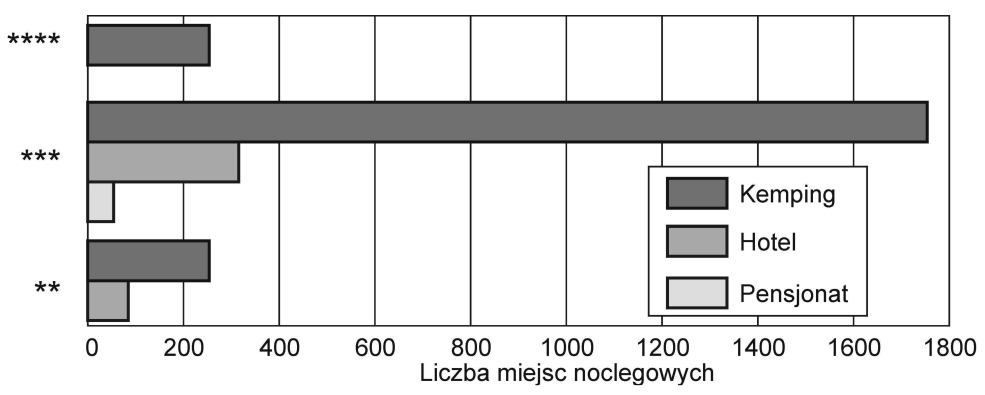

Rys. 6. Liczba miejsc noclegowych w wybranych kategoriach typów obiektów noclegowych Źródło: opracowanie własne na podstawie danych $\mathrm{CWOH}$ 
Analiza danych Centralnego Wykazu Obiektów Hotelarskich zamieszczonych w internetowym raporcie według stanu na koniec 2013 r. wykazuje w Łebie funkcjonowanie 12 obiektów skategoryzowanych: pięć hoteli, w tym trzy całoroczne, jeden pensjonat całoroczny oraz sześć kempingów działających sezonowo (rys. 6). Obiekty skategoryzowane oferują łącznie 2694 miejsc noclegowych. Najwięcej miejsc noclegowych według CWOH znajdowało się na kempingach, które dysponowały w sumie 2250 miejscami noclegowymi, co stanowiło 83,5\% ogólnej liczby obiektów skategoryzowanych.

Hotele posiadały łącznie 394 (14,6\%) miejsc noclegowych, w tym 310 miejsc w obiektach trzygwiazdkowych oraz 84 miejsca w hotelach dwugwiazdkowych.

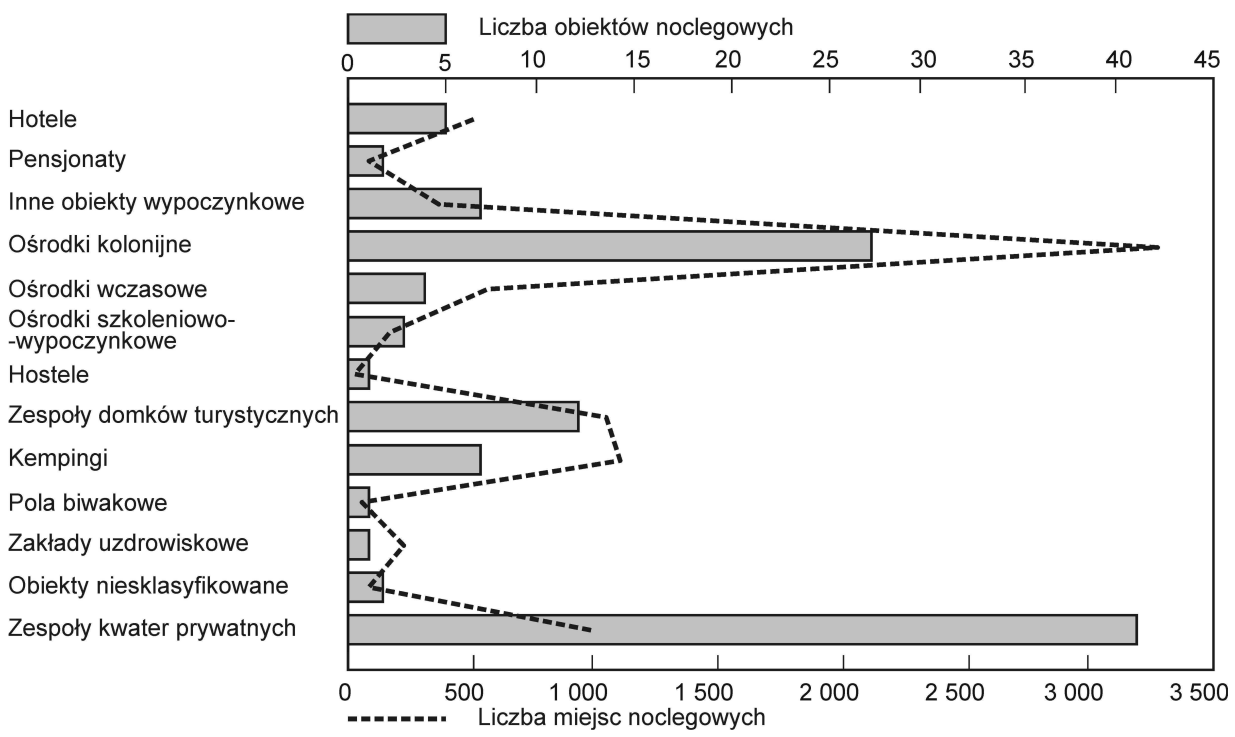

Rys. 7. Liczba obiektów i miejsc noclegowych w Łebie w 2013 r. z uwzględnieniem struktury rodzajowej bazy noclegowej

Źródło: opracowanie własne na podstawie danych Banku Danych Lokalnych GUS

Analiza zagospodarowania noclegowego Łeby w oparciu o dane statystyczne Banku Danych Lokalnych GUS według stanu za rok 2013 wskazuje na istnienie 113 obiektów noclegowych zakwaterowania zbiorowego (rys. 7). W tej liczbie odnotowano 14 obiektów hotelarskich oraz 99 innych obiektów noclegowych, w tym siedem kempingów, 12 zespołów domków turystycznych oraz 80 pozostałych obiektów noclegowych. Ze 113 obiektów zakwa- 
terowania zbiorowego znajdujących się w ewidencji GUS 16,7\% stanowiły obiekty całoroczne, natomiast 83,3\% obiekty sezonowe. Ogółem w ewidencji obiektów noclegowych w Łebie według Banku Danych Lokalnych GUS znalazło się 12 typów obiektów noclegowych. W grupie obiektów hotelarskich odnotowano pięć hoteli, dwa pensjonaty oraz siedem pozostałych obiektów hotelarskich. W ramach innych obiektów noclegowych było 27 ośrodków wczasowych, cztery ośrodki kolonijne, trzy ośrodki szkoleniowo-wypoczynkowe, jeden hostel, 12 zespołów domków turystycznych, siedem kempingów, jedno pole biwakowe, jeden zakład uzdrowiskowy oraz dwa obiekty niesklasyfikowane. Pozostałą liczbę 43 stanowiły obiekty zaklasyfikowane jako zespoły kwater prywatnych.

Liczba miejsc noclegowych we wszystkich obiektach noclegowych Łeby według Banku Danych Lokalnych GUS wynosiła 8437. Największy udział miały miejsca noclegowe w ośrodkach wypoczynkowych - $3258(38,6 \%$ ogółu miejsc noclegowych w mieście), 1093 na kempingach (ok. 13\%), 1031 w zespołach domków turystycznych (12,2\%), 993 w zespołach kwater prywatnych (11,7 ogółu miejsc w obiektach zakwaterowania zbiorowego w 2013 r.).

Analiza danych dotyczących zagospodarowania noclegowego Łeby według danych Banku Danych Lokalnych GUS wykazuje znaczne różnice ilościowe $\mathrm{w}$ porównaniu $\mathrm{z}$ ewidencją prowadzoną przez Urząd Miejski w Łebie. Warto jednocześnie zaznaczyć, że dane Urzędu Miejskiego w Łebie obejmują ewidencję wyłącznie obiektów nieskategoryzowanych. Według nich zasoby bazy noclegowej tworzą ośrodki wczasowe oraz obiekty zakwaterowania indywidualnego - pokoje gościnne. Liczba obu tych rodzajów obiektów wynosiła 449, z tego $73(16,3 \%)$ były obiektami całorocznymi. Ponadto odnotowano 67 ośrodków wczasowych, w tym 25 (37,3\%) obiektów to całoroczne oraz 382 kwatery prywatne, w tej liczbie 48 (12,6\%) miało charakter całoroczny.

Ośrodki wczasowe i pokoje gościnne łącznie dysponowały 5724 pokojami oraz 13992 miejscami noclegowymi, w tym 3080 tys. (tj. 22\%) miało charakter całoroczny. Pojemność noclegowa ośrodków wczasowych wynosiła 2661 jednostek mieszkalnych oraz 7098 miejsc noclegowych, z których 1806 (25,4\% ogółu) działało całorocznie. Pokoi gościnnych łącznie było 3063, a w nich 6894 miejsc noclegowych, z czego 1274 (18, 5\%) były miejscami całorocznymi.

Według danych Urzędu Miejskiego w Łebie w strukturze form własności obiektów noclegowych znajdujących się na terenie miasta dominują obiekty prywatne (tab. 1). Większość obiektów noclegowych jest własnością 
osób fizycznych (96,4\%). Z 433 obiektów noclegowych 53 (79,1\%) ośrodków wczasowych i $380(99,5 \%)$ pokoi gościnnych to obiekty prywatne. Udział innych form własności jest niewielki, wynosi zaledwie 3,6\%. Strukturę własnościową opartą głównie na własności krajowych osób fizycznych w nieznacznym stopniu uzupełnia własność innych krajowych podmiotów prywatnych, do których należy $13(19,4 \%)$ ośrodków wczasowych oraz dwa $(0,5 \%)$ pokoje gościnne. Sektor publiczny tworzy tylko jeden ośrodek wczasowy, będący własnością Skarbu Państwa.

Tab. 1. Struktura wielkościowa obiektów noclegowych według danych Urzędu Miejskiego w Łebie w 2013 r.

\begin{tabular}{|l|c|c|c|c|c|}
\hline \multirow{2}{*}{$\begin{array}{c}\text { Typ obiektu } \\
\text { noclegowego }\end{array}$} & \multicolumn{2}{|c|}{ Obiekty } & \multicolumn{3}{c|}{ Liczba } \\
\cline { 2 - 6 } & ogółem & całoroczne & $\begin{array}{c}\text { jednostek miesz- } \\
\text { kalnych }\end{array}$ & $\begin{array}{c}\text { miejsc nocle- } \\
\text { gowych }\end{array}$ & $\begin{array}{c}\text { miejsc cało- } \\
\text { rocznych }\end{array}$ \\
\hline Ośrodek wczasowy & 67 & 25 & 2661 & 7098 & 1806 \\
\hline Kwatery prywatne & 382 & 48 & 3063 & 6894 & 1274 \\
\hline
\end{tabular}

Źródło: opracowanie własne na podstawie danych Urzędu Miasta w Łebie.

Na potrzeby niniejszego opracowania dokonano inwentaryzacji zasobów bazy noclegowej, w oparciu o badania terenowe zrealizowane w sezonach turystycznych 2010 i 2012, oraz kwerendy zasobów internetowych baz 20 portali noclegowych ewidencjonujących bazę noclegową Polski.

Badania terenowe, weryfikacja wcześniej wymienionych danych $\mathrm{CWOH}$, danych statystycznych GUS, danych Urzędu Miasta Łeba oraz danych uzyskanych w drodze kwerendy zasobów internetowych 20 portali noclegowych ewidencjonujących bazę noclegową pozwoliły na zweryfikowanie w Łebie 936 obiektów noclegowych, które reprezentowały 16 różnych typów obiektów noclegowych. W tej liczbie odnotowano 341 obiekty całoroczne oraz 605 o charakterze sezonowym. Liczba obiektów całorocznych stanowiła więc zaledwie 36,0\% ogółu obiektów noclegowych w Łebie.

Liczbę miejsc noclegowych określono według stanu na 1.04.2015 r. na 46 514 miejsc noclegowych. W tej liczbie 11421 stanowiły miejsca noclegowe w obiektach całorocznych $(24,4 \%)$, natomiast 35093 miejsca były zlokalizowane w obiektach bazy sezonowej. Wskaźniki liczby obiektów oraz miejsc sezonowych w liczbie obiektów i miejsc noclegowych ogółem potwierdzają wybitnie sezonowy charakter funkcji turystycznej Łeby. 
W strukturze rodzajowej ogółu miejsc noclegowych w Łebie zdecydowanie zaznacza się dominacja miejsc noclegowych na kempingach - 12426 (27\% ogółu bazy noclegowej) oraz w kwaterach prywatnych - 12641 (ok. 27,1\% ogółu miejsc noclegowych). Widoczny jest dość duży udział w pojemności bazy noclegowej ogółem oraz w strukturze rodzajowej miejsc w ośrodkach wypoczynkowych - jest ich 8214 (ok. 18\% ogółu zasobów bazy noclegowej). Ponadto około 9\% ogółu miejsc noclegowych znajdowało się $\mathrm{w}$ pensjonatach (4047 miejsc), a 6\% w domach letniskowych (2809 miejsc). Odsetek miejsc noclegowych w obrębie pozostałych typów obiektów bazy noclegowej był marginalny i nie przekraczał 2\% (apartamenty - 1332 miejsc, domy wypoczynkowe - 1300, hotele - 1005, domy wczasowe - 1115; por. tab. 2).

Tab. 2. Struktura rodzajowa infrastruktury noclegowej w Łebie według stanu na 01.04.2015 r.

\begin{tabular}{|l|c|c|}
\hline \multicolumn{1}{|c|}{ Typ obiektu } & $\begin{array}{c}\text { Liczba miejsc } \\
\text { noclegowych }\end{array}$ & $\begin{array}{c}\text { Udział (\%) w liczbie miejsc } \\
\text { noclegowych ogółem }\end{array}$ \\
\hline Apartamenty & 1332 & 3 \\
\hline Domy wczasowe & 1115 & 2 \\
\hline Domy wypoczynkowe & 1300 & 3 \\
\hline Domy letniskowe & 2609 & 6 \\
\hline Hotele & 1005 & 27 \\
\hline Kempingi & 12426 & 27 \\
\hline Kwatery prywatne & 12641 & 1 \\
\hline Ośrodki kolonijne & 450 & 0 \\
\hline Ośrodki rekolekcyjne & 96 & 0 \\
\hline Ośrodki szkoleniowe & 70 & 18 \\
\hline Ośrodki wczasowe & 8214 & 9 \\
\hline Pensjonaty & 4047 & 1 \\
\hline Pole namiotowe & 405 & 1 \\
\hline Sanatorium & 560 & 0 \\
\hline Schronisko młodzieżowe & 64 & 0 \\
\hline Niesklasyfikowane & 180 & 100 \\
\hline Ogółem & 46514 & \\
\hline
\end{tabular}

Źródło: opracowanie własne na podstawie badań terenowych, danych statystycznych GUS, danych CWOH, danych Urzędu Miasta w Łebie oraz kwerendy zasobów internetowych portali noclegowych.

Analiza bazy gastronomicznej dokonana na podstawie badań terenowych, danych Urzędu Miejskiego w Łebie oraz danych uzyskanych w drodze kwerendy zasobów internetowych pozwoliła odnotować w Łebie 235 
obiektów gastronomicznych, z tego najwięcej w barach - 77 (około 33\%), smażalniach - $50(21,3 \%)$ i w obiektach zbiorowego żywienia - $30(12,8 \%$ ogółu obiektów gastronomicznych) (rys. 8). Łącznie ok. 80\% bazy gastronomicznej w mieście skoncentrowane było w obiektach sezonowych.

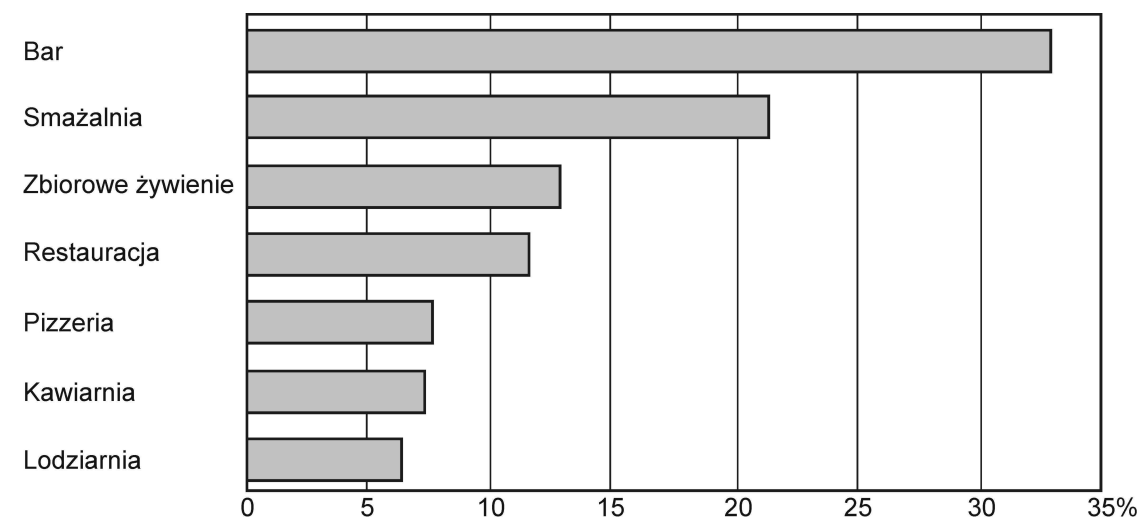

Rys. 8. Struktura bazy gastronomicznej w Łebie według stanu na 01.04.2015 r. Źródło: opracowanie własne na podstawie badań terenowych, danych statystycznych GUS, danych CWOH, danych Urzędu Miasta w Łebie oraz kwerendy zasobów internetowych portali noclegowych

Tab. 3. Struktura usług infrastruktury towarzyszącej w Łebie

\begin{tabular}{|l|c|}
\hline \multicolumn{1}{|c|}{ Typ usługi } & Liczba \\
\hline Baseny & 11 \\
\hline Firmy transportowe, i lokalni przewoźnicy & 30 \\
\hline Korty tenisowe & 4 \\
\hline Lokale rozrywkowe & 20 \\
\hline Rejsy wędkarskie i wycieczkowe & 25 \\
\hline Salony gier & 10 \\
\hline Szkoły żeglarskie i windsurfingu & 9 \\
\hline Przewodnickie i inne związane z organizacją turystyki & 13 \\
\hline Wypożyczalnie rowerów, quadów, skuterów & 14 \\
\hline Wypożyczalnie sprzętu wodnego & 5 \\
\hline Ogółem & 151 \\
\hline
\end{tabular}

Źródło: opracowanie własne na podstawie badań terenowych, danych statystycznych GUS, danych $\mathrm{CWOH}$, danych Urzędu Miasta w Łebie oraz kwerendy zasobów internetowych portali noclegowych.

Inwentaryzacja terenowa, analiza danych Urzędu Miasta w Łebie oraz zasobów internetowych dotycząca pozostałych obiektów zagospodarowania 
turystycznego w Łebie wykazała funkcjonowanie w miejscowości 151 obiektów i usługodawców (tab. 3) w zakresie szeroko rozumianej infrastruktury towarzyszącej związanej z transportem (30 przewoźników i firm transportowych), rozrywką (20 lokali rozrywkowych i 10 salonów gier), rekreacją (11 basenów, cztery korty tenisowe) oraz szeroko pojmowaną organizacją i obsługą turystów - 66 usługodawców.

\section{Podsumowanie}

Łeba rozwija się jako miejscowość turystyczno wypoczynkowa od drugiej połowy XIX w. Rozwinęła się na bazie naturalnych walorów wypoczynkowych związanych z nadmorskim położeniem. Dodatkowymi czynnikami wzmacniającymi znaczenie rozwoju turystyki w mieście z czasem stały się jej walory uzdrowiskowe, krajoznawcze oraz możliwości rozwoju turystyki kwalifikowanej (sporty wodne) i tematycznej (lebskie parki rozrywki). O dominującej roli turystyki w rozwoju społeczno-ekonomicznym miejscowości może świadczyć liczba podmiotów gospodarczych i osób fizycznych związanych bezpośrednio lub pośrednio z działalnością gospodarczą związaną z organizacją i obsługą ruchu turystycznego. Istotnym miernikiem funkcji turystycznej Łeby jest jej infrastruktura noclegowa (bardzo wysoka liczba miejsc noclegowych, silnie zróżnicowana struktura rodzajowa obiektów noclegowych) oraz znacząca i bardzo zróżnicowana liczba obiektów infrastruktury towarzyszącej. Jednocześnie charakter bazy noclegowej i większości obiektów infrastruktury gastronomicznej oraz towarzyszącej wskazuje na wyraźną sezonowość realizowanej funkcji turystycznej w miejscowości.

\section{Bibliografia}

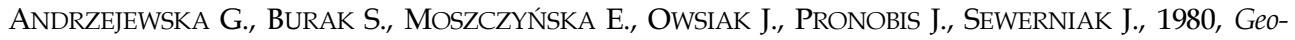
graficzne podstawy użytkowania turystycznego strefy nadmorskiej, Warszawa.

JAŻEWICZ I., RYDZ E., 2001, Turystyka jako czynnik rozwoju społeczno-ekonomicznego Łeby, Zeszyty Naukowe Wydziału Ekonomii i Zarządzania, 8, Koszalin.

JAŻEWICZ I., 2011, Strategiczna rola turystyki w rozwoju Łeby, [w:] Funkcja turystyczna miast, I. Jażdżewska (red.), XXI Konserwatorium Wiedzy o Mieście, Uniwersytet Łódzki, Łódź, s. 81-98.

MATCZAK A., RYDZ E., 2001, Koncepcja monitoringu ruchu turystycznego w strefie brzegowej Battyku (na przykładzie rejonu Ustka-Rowy), [w:] Turystyka jako czynnik rozwoju regionów, miast $i$ obszarów wiejskich, Wyższa Pomorska Szkołą Turystyki i Hotelarstwa, Zeszyty Naukowe, 1, Bydgoszcz, s. 183-193. 
MATCZAK A., 2005, Turystyka w przestrzeni miejskiej Ustki - polskiego kurortu nadbałtyckiego, "Turyzm", 15-1/2, s. 139-149.

MATCZAK A., 2006, Struktura przestrzenno funkcjonalna Ustki, - polskiego kurortu nadbattyckiego, [w:] Urbanizacja i społeczeństwo, B. Górz (red.), Akademia Pedagogiczna, Kraków, s. 179-194.

OŁDYTOWSKI R., 2008, Studium programowo-przestrzenne uzdrowiska Łeba. Założenia do planu uzdrowiska Łeba, Łeba.

PARZYCH K., 2009, Postrzeganie kurortu nadmorskiego przez turystów na przykładzie Łeby, „Problemy Ekologii Krajobrazu", XV, s. 139-145.

PARZYCH 2010, Determinants of tourist activity and tourist destination perception on the example of selected coastal resorts, The comparison of Ustka and Łeba resorts, „Baltic Coastal Zone”, 14, s. 87-99.

RYDZ E., 2011, Rola turystyki w rozwoju strefy nadmorskiej na przykładzie Pomorza Środkowego, [w:] Turystyka. Księga jubileuszowa w 70 rocznicę urodzin Profesora Stanistawa Liszewskiego, B. Włodarczyk (red.), Wyd. UŁ, Łódź, s. 319-336.

SZWICHTENBERG A., 1995, Gospodarka turystyczna w okresie przejściowym, Politechnika Koszalińska, Koszalin.

SZWICHTENBERG A., 2006, Gospodarka turystyczna polskiego woybrzeża, Politechnika Koszalińska, Koszalin. www.booking.com.

www.eholiday.pl.

www.e-nocleg.pl.

www.e-wczasy.pl.

www.fajnewczasy.pl.

www.ibed.pl.

www.inoclegi.pl.

www.interia.pl.

www.meteor.pl.

www.meteor-turystyka.pl.

www.nadmorze.pl.

www.noclegi.pl.

www.noclegi.pl.

www.noclegi-online.pl.

www.noclegiw.pl.

www.nocowanie.pl

www.przybrzegu.pl.

www.szukamnoclegu.com..pl.

www.trivago.pl.

www.turysta.pl. 